\title{
The law and the physician as principal investigator in sponsored clinical trials
}

William J. Sullivan QC

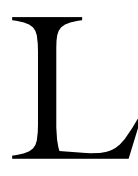

AW is about responsibilities, the breach of which gives rise to legal recourses. Two of those responsibilities that a principal investigator (P.I.) will face in sponsored clinical trials involve obligations to both the clinical trial subject and to the sponsor. The first is informed consent. The subject is legally entitled to it, the Research Ethics Board will want it in writing, and the contract with the sponsor will require that the P.I. obtain consent. The second is confidentiality. Contractually, there will be an obligation of confidentiality owed to the sponsor. Depending on the circumstances, there may be an obligation to the subject to disclose to him or her what might be confidential information under the sponsor's contract.

The potential for conflict between the commercial sponsor and the P.I. has increased in the past several years because of the proliferation of commercial sponsoring of drug trials. In the United States in 2001, there were 80,000 clinical trials conducted and some 20 million people enrolled as research subjects. ${ }^{1}$ More and more subjects are needed for the increasing number of trials. This need can result in problems for the subjects and ultimately problems for the investigators who fail to recognize their legal and ethical obligations. Dr. Califf, the Director of Duke Clinical Research Institute said:

"You go to trade meetings on clinical research; you go for two entire days and patients are not mentioned. The patient is an object to make money. Having patients is just the dirty price of doing business." 2

\section{Informed consent}

The concept of informed consent (as opposed to consent) is relatively new in law. It gained momentum following the Second World War with the trial of the Nazi doctors who carried out research on concentration camp subjects. The judgment in that trial sets out a number of research principles referred to sometimes as the Nuremberg Code and which in both law and ethics are still largely applicable today. Principle No. 1, in part, states:

"Before acceptance of a consent the subject must be told the nature, duration and purpose of the experiment; the method and means by which it is to be conducted; all inconveniences and hazards reasonably to be expected and the effects upon his health or person which may possibly come from his participation in the experiment."3

The Nuremberg Code was a legal document, and physicians wanted a medical expression of its principles. For that and other reasons the Declaration of Helsinki (which includes informed consent) came into existence in $1964^{3}$ and has been updated from time to time since then.

There are two important cases in Canada involving the investigator and informed consent in research. In the first, an engineering student at the University of Saskatchewan was offered $\$ 50.00$ to take part in a clinical trial. During the procedure, he suffered cardiac arrest and remained unconscious for three days. The court found the researcher had not informed the student of the purpose of the research, of the research drug (an anesthetic), that the researcher had no previous knowledge of the drug and that there was a risk involved with the use of an anesthetic. The subject was told a catheter would be inserted in a vein in his arm. He was not informed the catheter would be advanced to and through his heart. The court held:

"The subject of medical experimentation is entitled to a full and frank disclosure of all the facts, probabilities and opinions which a reasonable man might be expected to consider before giving bis consent."4

In the second case, a research subject suffered from a heart condition. He died of ventricular fibrillation from an adverse reaction to fluorescein, which was

Address correspondence to: William J. Sullivan QC, Guild, Yule \& Company, Barristers and Solicitors, P.O. Box 49170, 2000 Bentall Centre, 595 Burrard Street, Vancouver, B.C. V7X 1R7, Canada. Phone: 604-688-1221; Fax: 604-688-1315; E-mail: wj_sullivan@guildyule.com

This article is based on a talk given by the author at the annual meeting of the Canadian Anesthesiologists Society, in Victoria, in June, 2002. It formed part of the presentation on research ethics proposed and chaired by Dr. Joan Bevan. 
used in the study. He had not been told of the slight risk of death in the use of that drug. The court held:

"The duty to inform in matters relating to purely scientific experimentation is the most exacting possible. This duty includes the revelation of all risks including those which are rare or remote and especially those risks which may entail serious consequences." 5

The investigator's duty to make the necessary disclosure to the patient to obtain informed consent is mirrored in his or her contractual obligation to the sponsor to properly obtain that informed consent. The obligation may be in the contract or it may be in the protocol. Either way, the legal obligation is there.

For example, a research contract used in Canada provides (emphasis added):

"The investigator and the institutions shall carry out the clinical trial in accordance with the protocol, Canadian federal, provincial and local laws, regulations and other requirements and generally accepted medical standards."

A protocol used in Canada provides:

"For all trials not conducted under a U.S. IND, the principles of informed consent which offer the subject a greater protection (current revision of the Helsinki Declaration or local requirements) must be implemented."

The protocol may also set out the wording for the informed consent.

Where informed consent is not properly obtained from the subject, the investigator faces a potential liability for any damages suffered by that subject and faces, in addition, responsibility for any damages suffered by the sponsor. These can be considerable particularly if the result is that the clinical trial is stopped or delayed.

\section{Confidentiality}

"Please be aware that Apotex will take all possible steps to ensure that the obligations of confidentiality are met and will vigorously pursue all legal remedies in the event there is any breach of these obligations." Extract from a letter to Dr. Nancy Olivieri ${ }^{6}$

The Nancy Olivieri case is Canada's example of what can go wrong if there is failure by a P.I. to understand or appreciate the contract to be signed with the sponsor. The case involved a number of conflicts (sometimes complex) between institutions and individuals. It raises questions of academic freedom and research ethics. The confidentiality issue, however, legally was simple. The contract between the sponsor and Dr. Olivieri provided that during the term of the contract, and for a period of time thereafter, research results were confidential and there was to be no disclosure without the written consent of Apotex.
A contract which prohibits disclosure of information to clinical trial subjects where a failure to disclose could harm the subjects may well be void as against public policy. But a possible defence in such a lawsuit is not as good as having a contract where there is no basis at all for such a lawsuit.

The Nancy Olivieri Inquiry suggested this wording be used in any contract between an investigator and the sponsor:

"If I have concerns about the safety ... of the study drug ... I have the right to disclose relevant information ... to participants in the study ... and the scientific community."

Following are two excerpts from the informed consent portion of protocols used in Canada. Both can protect the investigator in disclosing to the subject what might otherwise be confidential information under the sponsor's contract, provided the sponsor has approved the consent form.

"If any significant new findings regarding the study, or medications become available during the course of this study which may affect your willingness to participate, the investigator will inform you."

"We will tell you about new information that may affect your health, your welfare or your willingness to stay in the study."

Hospitals are usually parties to research contracts. They often have trained people who vet these contracts. This can be of assistance to the physician. However, it is the physician who is ultimately responsible under the contract and who must understand what he or she is signing. Sometimes physicians are asked by sponsors to sign separate confidentiality agreements. This should not be done without the hospital or other involved institutions being satisfied as to their content and the physician satisfied he or she can comply. This may also require obtaining legal advice. The confidentiality agreement may say no publication is permitted of the sponsor's proprietary information, which may be reasonable. However, if proprietary information is defined in the confidentiality agreement to include all study results, then it is unreasonable.

There are a number of guidelines for both the sponsor and the investigator on disclosure and where confidentiality is not appropriate. They include:

\section{The Tri-Council Policy Statement:}

"Additional information that may be required for some projects.

i. An assurance that new information will be provided to the subjects in a timely manner whenever such information is relevant to a subject's decision to continue or withdraw from participation." 
2. The Health Canada Consolidated Guideline. Good Clinical Practice:

"Consent form ... should be revised whenever important new information becomes available that may be relevant to the subject's consent ... The subject ... should be informed in a timely manner if new information becomes available that may be relevant to the subject's willingness to continue participation in a trial." 9

3. The regulations of the Food and Drugs Act of Canada:

"Every sponsor shall ensure that a clinical trial is conducted in accordance with good clinical practices." 10

"Good clinical practice means generally accepted clinical practices that are designed to ensure the protection of the rights, safety and well-being of clinical trial subjects...". ${ }^{11}$

4. Journal articles are clear on this issue. For example:

"These (research) contracts should give the researchers a substantial say in trial design, access to raw data, responsibility for data analysis and interpretation and the right to publish ...". ${ }^{12}$

5. Again the Tri-Council Policy Statement:

"The researcher's duty (is) to disseminate the analysis and interpretation of the results to the research community ... researcher and Research Ethics Boards may exert pressure to alleviate this deficiency in the dissemination of research results by resisting publication bans proposed in research protocols on the basis of ethical obligations of truthfulness and the integrity of research." 13

\section{Conclusion}

The P.I. has ethical duties to the clinical trial subject as well as legal responsibilities to both the clinical trial subject and to the sponsor of the clinical trial. The P.I. is legally obligated to both the subject and (contractually) to the sponsor to obtain informed consent. There may be a legal duty to the subject to disclose information during the clinical trial which the sponsor's contract requires be kept confidential. The P.I. can be responsible for damages suffered by the subject. The P.I. can also be responsible for damages if he or she breaches the contract of the sponsor. These damages could be considerable. It is important that before signing a contract P.I.s know what their legal obligations are to the sponsor and be satisfied they can honour them without breaching their ethical and legal responsibilities to the subject.
Lewis et al. put it well when they said in the context of rules for governing the university-industry relationship:

"Some bargains are Faustian, and some horses are Trojan. Dance carefully with the porcupine, and know in advance the price of intimacy." 14

By all means, dance with the porcupine, but read and understand the contract first.

\section{La loi et le médecin comme chercheur prin- cipal des études clini- ques commanditées}

Le présent article est tiré d'une conférence faite par l'auteur lors du congrès annuel de la Société canadienne des anesthésiologistes à Victoria, en juin 2002. Il fait partie de la présentation sur l'éthique de la recherche proposée et présidée par le Dr Joan Bevan.

La loi traite de responsabilités dont la transgression peut donner lieu à des actions en justice. Deux de ces responsabilités auxquelles un chercheur principal (C.P.) doit faire face pendant des études cliniques commanditées comprennent des obligations envers le patient et envers le commanditaire de l'étude. La première est le consentement éclairé. Le sujet y a légalement droit, le Comité d'éthique pour la recherche l'exige par écrit et le contrat avec le commanditaire exige que le C.P. obtienne ce consentement. La seconde obligation est la confidentialité. Par contrat, il y a une obligation de confidentialité envers le commanditaire. Selon les circonstances, on pourrait être obligé de dévoiler au sujet des renseignements jugés confidentiels par le contrat avec le commanditaire.

Le potentiel de conflit entre le commanditaire commercial et le C.P. a augmenté au cours des dernières années à cause de la prolifération de la commandite commerciale des études cliniques. En 2001 aux États-Unis, il y a eu 80000 études cliniques et 20 millions de personnes environ y ont participé comme sujets de recherche. ${ }^{1}$ Il faut de plus en plus de sujets pour le nombre croissant d'études. Cette situation peut causer des problèmes aux sujets et, à la limite, aux chercheurs qui négligent de reconnaître leurs obligations légales et éthiques. Dr Califf, directeur du Duke Clinical Research Institute a déclaré : 
"Vous participez à des réunions commerciales sur la recherche clinique; vous y discutez pendant deux jours entiers sans même parler des patients. Le patient devient un objet pour faire de l'argent. La présence de patients ne représente que le prix à payer pour faire des affaires.” 2

\section{Le consentement éclairé}

Le concept de consentement éclairé (à la différence du consentement) est relativement nouveau dans la loi. Il s'est imposé à la suite de la Seconde Guerre mondiale avec le procès des médecins nazis qui ont fait des recherches sur les sujets des camps de concentration. Le jugement émis à ce procès énonce un certain nombre de principes de recherche mentionnés parfois comme le Code de Nuremberg et qui sont encore largement applicables aujourd'hui aux plans de la loi et de l'éthique. Le principe no 1 dit, entre autres :

"Avant que le sujet expérimental accepte, il faut donc le renseigner exactement sur la nature, la durée et le but de l'expérience, ainsi que sur les méthodes et moyens employés, les dangers et les risques encourus et les conséquences pour sa santé ou sa personne qui peuvent résulter de sa participation à cette expérience. "3

Le Code de Nuremberg est un document légal et les médecins voulaient une formulation médicale de ses principes. Pour cette raison, entre autres, la Déclaration d'Helsinki (qui comprend le consentement éclairé) a été rédigée en $1964^{3}$ et a été mise à jour à quelques reprises depuis.

Au Canada, deux cas importants concernent le chercheur et le consentement éclairé en recherche. Dans le premier cas, un étudiant en ingénierie de l'University of Saskatchewan s'est vu offrir 50,00 \$ pour participer à une étude clinique. Pendant l'application de la technique, il a subi un arrêt cardiaque et est demeuré inconscient pendant trois jours. Le tribunal a jugé que le chercheur n'avait pas informé l'étudiant sur l'objectif de la recherche et sur le médicament utilisé (un anesthésique), sur le fait que le chercheur n'avait pas de connaissance antérieure du médicament et qu'il y avait un risque à utiliser un anesthésique. On avait dit au sujet qu'un cathéter serait inséré dans une veine de son bras. On ne lui avait pas dit que le cathéter serait poussé au niveau du cœur et au delà du cour. Le tribunal a déclaré :

"Le sujet d'une expérience médicale a le droit de recevoir un exposé complet et précis de tous les faits, possibilités et opinions que toute personne raisonnable s'attend à devoir considérer avant de donner son consentement. '4

Dans le second cas, un sujet de recherche a souffert de troubles cardiaques. Il est décédé à la suite de fibrillation ventriculaire en réaction à la fluorescéine utilisée dans l'étude. On ne lui avait pas mentionné le faible risque de décès lié à l'usage de ce médicament. Le tribunal a déclaré :

"Le devoir d'informer sur les questions relatives à l'expérimentation purement scientifique est le plus rigoureux possible. Ce devoir comprend la divulgation de tous les risques, incluant ceux qui sont rares ou éloignés et, spécialement, les risques dont les conséquences peuvent être sérieuses. "

Le devoir du chercheur de fournir au patient les renseignements nécessaires à l'obtention de son consentement éclairé est identique à son obligation contractuelle envers le commanditaire d'obtenir comme il se doit ce consentement éclairé. L'obligation peut faire partie du contrat ou du protocole. D'une façon ou de l'autre, l'obligation légale existe.

Par exemple, un contrat de recherche utilisé au Canada stipule (c'est nous qui soulignons) :

"Le chercheur et les institutions doivent réaliser l'étude clinique selon le protocole, les lois canadiennes d'intérêt fédéral, provincial et local, les règlements et autres conditions et les normes généralement acceptées."

Un protocole utilisé au Canada stipule :

"Pour toutes les études menées comme sous l'appellation américaine de DNR (drogue nouvelle de recherche), les principes du consentement éclairé qui offrent au sujet une plus grande protection (version actuelle de la Déclaration d'Helsinki ou exigences locales) doivent être mis en application.”

Le protocole peut aussi indiquer les termes du consentement éclairé.

Si le consentement éclairé du sujet n'est pas convenablement obtenu, le chercheur peut être tenu responsable de tout préjudice causé au sujet et aussi au commanditaire. Ces dommages peuvent être particulièrement importants s'il en résulte un retard ou un arrêt de l'étude.

\section{La confidentialité}

"Veuillez noter qu'Apotex prendra toutes les mesures possibles pour s'assurer que les obligations de confidentialité ont été respectées et que des recours en justice seront rigoureusement exercés dans l'éventualité d'une violation de ces obligations." Extrait d'une lettre au Dr Nancy Olivieri ${ }^{6}$

Le cas de Nancy Olivieri constitue l'exemple canadien des problèmes qui peuvent survenir lorsqu'un C.P. ne comprend pas bien ou n'évalue pas exactement la portée du contrat à signer avec le commanditaire. Le cas comporte un certain nombre de conflits (parfois complexes) entre les institutions et les individus. Il soulève des questions de liberté universitaire et d'éthique de la recherche. La question de la confidentialité était, toutefois, simple au plan juridique. Le 
contrat entre le commanditaire et le Dr Olivieri stipulait que pendant le terme du contrat, et pour un certain temps par la suite, les résultats de la recherche étaient confidentiels et ne pouvaient être rendus publics sans le consentement écrit d'Apotex.

Un contrat qui interdit la transmission de renseignements aux participants d'une étude clinique, au cours de laquelle un défaut de divulgation leur porterait atteinte, pourrait bien être annulé comme étant au détriment de l'ordre public. La défense possible dans le cas d'une action judiciaire semblable n'est pas aussi bonne que dans le cas d'un contrat où il n'existe aucun fondement pour un tel recours.

L'enquête judiciaire sur Nancy Olivieri suggérait l'utilisation du libellé suivant dans tout contrat passé entre un chercheur et un commanditaire :

"Si j'ai des doutes sur la sécurité ... du médicament à l'étude ... j'ai le droit de répéler les renseignements pertinents ... aux participants de l'étude ... et au milieu scientifique. "

Voici deux extraits de la partie des protocoles canadiens traitant du consentement éclairé.

Les deux protègent le chercheur qui révèle au sujet ce qui, autrement, serait de l'information confidentielle d'après le contrat avec le commanditaire, pourvu que ce dernier ait approuvé le formulaire du consentement.

"Si, pendant le déroulement de l'étude, de nouveaux résultats significatifs concernant l'étude ou les médicaments et susceptibles de modifier votre participation sont disponibles, le chercheur vous en informera."

"Nous vous ferons part de tout nouveau renseignement qui pourrait affecter votre santé, votre bien-être ou votre consentement à participer à l'étude."

Les hôpitaux prennent généralement part aux contrats de recherche. Souvent, ils forment les personnes qui examinent ces contrats. Ce qui peut constituer un soutien au médecin. Cependant, c'est le médecin qui est finalement responsable selon le contrat et c'est lui qui doit comprendre ce qu'il signe. Parfois, les commanditaires demandent aux médecins de signer des ententes de non-divulagation séparées. Cela ne devrait pas se faire sans que l'hôpital ou d'autres institutions ne soient satisfaits du contenu de l'entente et que le médecin n'accepte de s'y conformer. L'entente pourrait aussi nécessiter la production d'un avis juridique. L'entente de confidentialité peut admettre qu'aucune publication de renseignements exclusifs concernant le commanditaire ne soit permise, ce qui peut être raisonnable. Par ailleurs, si les renseignements exclusifs définis dans l'entente de confidentialité comprennent tous les résultats de l'étude, c'est alors abusif.

Il existe des directives pour le commanditaire et le chercheur concernant la diffusion des résultats et les li- mites de la confidentialité. Ces directives comprennent :

1. L'Énoncé politique des trois conseils:

"Informations supplémentaires pouvant être exigées pour certains projets.

i. L'assurance de fournir au sujet en temps opportun tous les nouveaux renseignements susceptibles de remettre en cause leur décision de continuer, ou non, à prendre part à la recherche's

2. Les directives consolidées de Santé Canada. Les bonnes pratiques cliniques:

"Le formulaire de consentement ... doit être révisé lorsque de nouveaux renseignements importants susceptibles d'avoir une incidence sur le consentement du sujet sont disponibles ... Le sujet ... doit être informé rapidement des nouveaux renseignements pouvant influer sur le désir du sujet de continuer à participer à l'essai. "9

3. Les règlements de la Loi sur les aliments et drogues du Canada:

"Tout commanditaire doit s'assurer que l'étude clinique est réalisée selon de bonnes pratiques cliniques. ${ }^{~} 0$

"De bonnes pratiques cliniques signifient généralement des pratiques cliniques acceptées, déterminées pour assurer la protection des droits, la sécurité et le bien-être des sujets d'essais cliniques ...". ${ }^{11}$

4. Les articles scientifiques sont clairs à ce sujet. Ainsi :

"Ces contrats (de recherche) doivent permettre au chercheur de participer substantiellement an devis de l'étude, d'accéder aux données brutes, de prendre la responsabilité de l'analyse et de l'interprétation des données et lui accorder le droit de publier ...”. ${ }^{12}$

5. Un autre extrait de l'Énoncé politique des trois conseils :

"Le devoir des chercheurs de diffuser l'analyse et l'interprétation des résultats dans le milieu de la recherche ... les chercheurs et les Comités d'éthique de la recherche peuvent exercer des pressions afin de pallier ce manque de diffusion des résultats de recherche en s'opposant aux interdits de publication proposés dans les protocoles de recherche, se fondant pour cela sur les obligations d'ordre éthique de véracité et d'intégrité de la recherche. 3

\section{Conclusion}

Le C.P. a des obligations éthiques envers le patient participant à l'étude clinique et des responsabilités légales envers le sujet qui participe à l'étude et envers 
le commanditaire de l'étude. Le C.P. est légalement obligé, face au sujet et, par contrat, face au commanditaire, d'obtenir un consentement éclairé. Pendant l'étude clinique, il pourrait exister une obligation légale de divulguer des renseignements que le contrat avec le commanditaire exigeait de garder confidentiels. Le C.P. peut être tenu responsable de préjudices subis par le sujet. Le C.P. peut être aussi responsable de préjudices s'il brise le contrat qui le lie au commanditaire. Ces préjudices peuvent être considérables. Il est important qu'avant de signer un contrat les C.P. sachent quelles sont les obligations légales envers le commanditaire et soient certains de pouvoir y répondre sans manquer à leurs responsabilités éthiques et légales envers le sujet.

Lewis et coll. l'ont bien démontré en disant que dans le contexte des règles qui gouvernent la relation entre l'université et l'industrie :

"Certains marchés sont faustiens et certains chevaux sont troyens. Valsez prudemment avec le porc-épic, et sachez d'avance le prix de l'intimité. 44

On vous encourage à valser avec le porc-épic, mais assurez-vous de lire et de comprendre le contrat d'abord.

\section{References}

1 Lemonick MD, Goldstein A. At your own risk. Time Magazine, April 22, 2002: 41-9.

2 Eichenwald K, Kolata G. Drug trials hide conflicts for doctors. The New York Times, May 16, 1999.

3 Vollmann J, Winau R. Informed consent in human experimentation before the Nuremberg code. BMJ 1996; 313: 1445-9.

4 Halushka v. University of Saskatchewan. WWR 1965; 52: 608 .

5 Weiss v. Solomon. CCLT 1989; 48: 280.

6 Shuchmann M. Legal issues surrounding privately funded research caused furore in Toronto. CMAJ 1998; 159: 983-4.

7 Thompson J, Baird P, Downie J. Report of the Committee of Inquiry on the case involving Dr. Nancy Olivieri, the Hospital for Sick Children, the University of Toronto and Apotex Inc., October 26, 2001. http:// is.dal.ca/jgdownie/coi/olivieri\%20inquiry\%20 report.pdf.

8 Medical Research Council of Canada, Natural Sciences and Engineering Research Council of Canada and Social Sciences and Humanities Research Council of Canada. Tri-council Policy Statement: Ethical Conduct for Research Involving Humans, August, 1998: 1.7. http:// www.nserc.ca/programs/ethics/english/policy.htm.

9 Good Clinical Practice: Consolidated Guideline. Health Canada, Section 4.8.2. Health Canada Publications. www.hc-sc.gc.ca/hpb-dgps/therapeut.
10 The Food and Drug Regulations under the Food and Drugs Act of Canada F 27 R.S.C. 1985, as amended; C.05.010. Vol 135, No 13, Canada Gazette.

11 The Food and Drug Regulations under the Food and Drugs Act of Canada F 27 R.S.C. 1985, as amended; C.05.001. Vol 135, No 13, Canada Gazette.

12 Davidoff F, DeAngelis CD, Drazen J M, et al. Sponsorship, authorship and accountability. CMAJ 2001; 165: 786.

13 Medical Research Council of Canada, Natural Sciences and Engineering Research Council of Canada and TriCouncil Policy Statement: Ethical Conduct for Research Involving Humans. August, 1998: 7.5 http:// www.nserc.ca/programs/ethics/english/policy.htm.

14 Lewis S, Baird P, Evans RG, et al. Dancing with the porcupine: rules for governing the university-industry relationship. CMAJ 2001; 165: 783. 